\title{
Impact of entomopathogenic nematodes on Africanized honey bees Apis mellifera L. (Hymenoptera: Apidae) workers
}

\section{Impacto de nematoides entomopatogênicos sobre operárias de Apis mellifera L. (Hymenoptera: Apidae) Africanizada}

\author{
Gabriela Libardoni ${ }^{1 *}$; Raiza Abati²; Amanda Roberta Sampaio ${ }^{2}$; Fernanda Caroline \\ Colombo $^{2}$; Rodrigo Mendes Antunes Maciel ${ }^{3}$; Bruna Guide ${ }^{1}$; Fabiana Martins \\ Costa-Maia ${ }^{4}$; Everton Ricardi Lozano ${ }^{5}$; Pedro Manuel Oliveira Janeiro Neves ${ }^{6}$; \\ Michele Potrich ${ }^{5}$
}

Highlights:

Nematodes reduced Apis mellifera longevity.

Higher mortality rate was found when exposed to Steinernema.

Direct spraying of Heterorhabditis on honey bees is selective.

\begin{abstract}
Africanized honey bee populations (Apis mellifera L.) have been decreasing mainly due to the intense use of synthetic insecticides associated with pollution and climate change. To minimize these impacts on the environment and bee populations, the use of biological control agents has been intensified. These products are generally safer for non-target insects, such as bees, which are important pollinating insects. Thus, the objective of this study was to evaluate the impact of entomopathogenic nematodes on the longevity of the Africanized honey bee A. mellifera workers. Seven treatments were used: Heterorhabditis amazonensis, Heterorhabditis bacteriophora, Heterorhabditis indica, Steinernema carpocapsae, Steinernema feltiae, and Steinernema rarum, at a concentration of 40 infective juveniles per $\mathrm{cm}^{2}\left(\mathrm{IJs} / \mathrm{cm}^{2}\right)$, and a control in which autoclaved distilled water was used. Two bioassays were performed: 1) spraying nematodes on the workers and 2) spraying nematodes on glass plates, in which the bees remained for two hours. Each treatment consisted of five replicates with 20 bees each. Bees were kept in cages of PVC $(20 \times 10 \mathrm{~cm})$ covered with a voile fabric and provided pieces of cotton soaked in water and Candy paste. The cages were kept in a climatized room $\left(27 \pm 2{ }^{\circ} \mathrm{C}\right.$ temperature, 60 $\pm 10 \%$ relative humidity, and $12 \mathrm{~h}$ photophase) and the mortality was evaluated from 12 to 240 hours. In bioassay 1, the three treatments with nematodes of the genus Steinernema reduced the longevity of the workers $(103.9,96.3$, and 99.6 h) when compared to treatments with Heterorhabditis (149.7,
\end{abstract}

\footnotetext{
' Discentes do Curso de Doutorado Programa de Pós-Graduação em Agronomia, Universidade Estadual de Londrina, UEL, Londrina, PR, Brasil. E-mail: gabrielalibardoni@gmail.com; bruhguide@gmail.com

2 Discentes do Curso de Mestrado do Programa de Pós-Graduação em Agroecossistemas, Universidade Tecnológica Federal do Paraná, UTFP, Campus Dois Vizinhos, Dois Vizinhos, PR, Brasil. E-mail: raizaabati@gmail.com; amandarobertasampaio@ gmail.com; fer.colombo@hotmail.com; evertonloz@gmail.com; profmichele@gmail.com

3 Discente do Curso de Mestrado do Programa de Pós-Graduação em Zootecnia, PPGZO, UTFPR, Campus Dois Vizinhos, Dois Vizinhos, PR, Brasil. E-mail: digoantunes@gmail.com

4 Prof $^{\mathrm{a}}$ Dr$^{\mathrm{a}}$, Programa de Pós-Graduação em Zootecnia, PPGZO, UTFPR, Campus Dois Vizinhos, Dois Vizinhos, PR, Brasil. E-mail: fabeezoo@gmail.com

5 Profs. Drs., Programa de Pós-Graduação em Agroecossistemas, UTFPR, Campus Dois Vizinhos, Dois Vizinhos, PR, Brasil. E-mail: evertonloz@gmail.com; profmichele@gmail.com

6 Prof. Dr., Programa de Pós-Graduação em Agronomia, UEL, Londrina, PR, Brasil. E-mail: pedroneves@uel.br

* Author for correspondence
} 
126.8, and $134.7 \mathrm{~h})$, of which, only H. amazonensis (149.7 h) did not differ from the control (166.0 h). In bioassay 2, all treatments reduced the longevity of honey bees ( 155.4 to $93.9 \mathrm{~h})$ in relation to the control $(176.1$ h). Entomopathogenic nematodes, especially Heterorhabditis, need to be tested using other methodologies and for different durations of exposure and application because in the laboratory, they were less selective to $A$. mellifera.

Key words: Africanized honey bee. Biological control. Steinernema spp. Heterorhabditis spp.

\section{Resumo}

As populações de abelhas africanizadas (Apis mellifera L.) vêm diminuindo devido, principalmente, ao intenso uso de inseticidas sintéticos. Desde modo, o emprego de agentes de controle biológico tem-se intensificado de forma a minimizar este impacto no ambiente. Estes produtos são, de modo geral, mais seguros aos insetos não-alvos, como as abelhas que são importantes insetos polinizadores. Desta forma, o objetivo deste trabalho foi avaliar os efeitos de nematoides entomopatogênicos utilizados para controle de insetos pragas, sobre a longevidade de operárias de A. mellifera africanizada. Foram utilizados sete tratamentos: Heterorhabditis amazonensis, Heterorhabditis bacteriophora, Heterorhabditis indica, Steinernema carpocapsae, Steinernema feltiae e Steinernema rarum, na concentração de 40 juvenis infectantes por $\mathrm{cm}^{2}\left(\mathrm{JIs} / \mathrm{cm}^{2}\right)$, e como testemunha água destilada autoclavada. Para isso foram realizados dois bioensaios: 1) Pulverização dos nematoides sobre as operárias e 2) Pulverização dos nematoides em placas de vidro, nas quais as abelhas permaneceram por duas horas em contato. Cada tratamento foi composto por cinco repetições com 20 abelhas cada. As abelhas foram mantidas em gaiolas de PVC $(20 \times 10 \mathrm{~cm})$ cobertas com tecido voile e fornecidos pedaços de algodão embebido em água e pasta Candy. As gaiolas foram mantidas em sala climatizada $\left(27 \pm 2{ }^{\circ}\right.$ C, U.R. $60 \pm 10 \%$, fotofase de 12 h) e a mortalidade avaliada de 12 até 240 horas. No bioensaio 1 os três tratamentos com nematoides do gênero Steinernema reduziram a longevidade das operárias (103,9; 96,3 e 99,6 horas) quando comparados aos tratamentos com Heterorhabditis (149,7; 126,8 e 134,7 horas). Entretanto, dentre estes apenas H. amazonensis (149,7 horas) não diferiu da testemunha (166,0 horas). No bioensaio 2 , todos os tratamentos reduziram a longevidade das abelhas $(155,4$ a 93,9 horas) em relação à testemunha $(176,1$ horas). Os nematoides entomopatogênicos, especialmente Heterorhabditis, necessitam ser testados em outras metodologias e em diferentes tempos de exposição e aplicação, pois em laboratório se mostraram pouco seletivos a A. mellifera.

Palavras-chave: Abelha africanizada. Controle biológico. Steinernema spp. Heterorhabditis spp.

In natural habitats where Apis mellifera L. (Hymenoptera: Apidae) honey bees occur, they play a fundamental role in the ecology, evolution, and conservation of plants, as they act as pollinators of various species (Hung, Kingston, Albrecht, Holway, \& Kohn, 2018). In addition, these insects are responsible for perpetuating various plant species by directly increasing fruit and seed quality and production (Ballantyne, Baldock, Rendell, \& Willmer, 2017).

In recent years, beekeepers have realized that the mortality of honey bees near the hives could be due to contamination by pesticides (Calatayud-Vernich, Calatayud, Simó, Suarez-Varela, \& Picó, 2016). In addition, since 2006, studies have shown a possible decrease in bee colonies and the term Colony Collapse Disorder (CCD) was coined (Costa-Maia, Lino-Lourenço, \& Toledo, 2010). The causes of CCD include natural causes such as stress caused by pathogens, parasites, and predators, unnatural causes such as improper colony management, pesticide use, and malnutrition, and could be the result of a combination of two or more factors (Pires et al., 2016).

Among all these factors that cause colony mortality and CCD, the major contributors are synthetic insecticides. Therefore, the use of biological and alternative control agents should be 
tested, although they are generally safer for nontarget insects such as honey bees (Oliveira, 2015; Pires et al., 2016; Libardoni et al., Colombo et al., 2020).

In biological control, living organisms (predators, parasitoids, and entomopathogens, such as bacteria, fungi, nematodes, and viruses) are used to control agricultural pests (Blackburn, Shapiroilan, \& Adams, 2016) and minimize the effect of insecticides, which sometimes kill or repel nontarget organisms such as pollinating insects.

The use of Heterorhabditis bacteriophora and Steinernema colombiense entomopathogenic nematodes for the control of leafhoppers Aeneolamia sp. (Hemiptera: Cercopidae) has been shown to be effective, altering their longevity, killing $100 \%$ and $75 \%$ of insects, respectively, 12 days after nematode inoculation (Aristizábal et al., 2015).

Among the entomopathogenic microorganisms, nematodes have some advantages, as they adapt to new environments, are specific to insects, and do not harm other animals or plants (Lewis, Campbell, Gri, Kaya, \& Peters, 2006). Thus, it is necessary to study the impact of entomopathogenic nematodes used in biological control on non-target organisms. The concern regarding honey bees is that nematodes can proliferate in the carcasses of dead bees and, when unnoticed by the other worker bees in the box, can infect the bee colony or spread to a larger area, causing mortality or even abandonment of the colony by the bees (Dutka, Mcnulty, \& Williamson, 2015). In this context, this study aimed to evaluate the impact of entomopathogenic nematodes used to control pest insects on the longevity of Africanized bee $A$. mellifera workers.

The study was carried out at the State University of Londrina (UEL) and the Federal University of Technology Paraná, Campus Dois Vizinhos (UTFPR-DV). Emerged worker bees (with $48 \mathrm{~h}$ of emergence) were obtained from the apiary at the UTFPR-DV, the Beekeeping Teaching and Research Unit (UNEPE-Apicultura). Frames with 19-day-old larvae were removed from the hive, placed in Kraft paper bags, which were perforated and wrapped in voile fabric taken to the Biological Control Laboratory, and stored in a climatized chamber (30 $\pm 2{ }^{\circ} \mathrm{C}$ temperature and $60 \pm 5 \%$ relative humidity), where they remained for two days for the emergence of the worker bees.

The nematodes were obtained from six isolates of two genera of nematodes: Heterorhabditis amazonensis (RSC 05 - Benjamin Constant, AM, Brazil), Heterorhabditis bacteriophora (HP 88, New Jersey, USA), Heterorhabditis indica (IBCB-n 05 Itapetininga, SP, Brazil), Steinernema carpocapsae (IBCB-n 02 - Florida, USA), Steinernema feltiae (IBCB-n 47 - Florida, USA), and Steinernema rarum (PAM - Aceguá, RS, Brazil), which were multiplied in vivo, following the methodology described by Molina and Lopes (2001), in the last instar of the honeycomb moth, Galleria mellonella L. (Lepidoptera: Pyralidae) caterpillar. They were then applied to the honey bees. In both bioassays, a concentration of 40 infective juveniles (IJs) $/ \mathrm{cm}^{2}$, totaling $290 \mu \mathrm{L}$ (which was adequate concentration for the volume used and the volume used was determined to ensure that the bees did not drown).

Bioassay 1: spraying the nematodes on the workers

The emerged honey bees were anesthetized with $\mathrm{CO}_{2}$ for up to $120 \mathrm{~s}$ and separated into groups of 10 individuals. They were placed in glass Petri dishes $(15 \mathrm{~cm} \varnothing \times 1.5 \mathrm{~cm}$ high $)$ and $290 \mu \mathrm{L}$ of the nematode suspension $\left(40 \mathrm{IJ} / \mathrm{cm}^{2}\right)$ was sprayed using a Potter tower coupled with a constant pressure pump (1.2 $\mathrm{kgf} / \mathrm{cm}^{2}$ ). After spraying, the workers of two Petri dishes (totaling 20 bees) were transferred to PVC cages $(20 \mathrm{~cm}$ high $\times 10 \mathrm{~cm} \varnothing)$, where a cotton soaked in water and Candy paste (50 g sugar + $10 \mathrm{~mL}$ honey) was provided (Brighenti, Carvalho, Carvalho, Brighenti, \& Carvalho, 2007; Carvalho, Carvalho, Carvalho, Bueno, \& Baptista, 2009).

The bioassay was kept in a climatized room (26 $\pm 2{ }^{\circ} \mathrm{C}, 60 \pm 5 \%$ relative humidity) and honey bee 
mortality was evaluated at $12,24,48,72,96,120$, $144,168,192,216$, and $240 \mathrm{~h}$ after the nematodes were sprayed (methodology adapted from Baptista, Carvalho, Carvalho, Carvalho, \& Bueno, 2009). After the mortality evaluation, the insects were removed from the cages and dissected to verify the presence of the nematode and, consequently, to confirm that the death was caused by the entomopathogen.

Bioassay 2: contact of worker bees with nematodes

Using Potter Tower coupled with a constant pressure pump $\left(1.2 \mathrm{kgf} / \mathrm{cm}^{2}\right), 290 \mu \mathrm{L}$ of the nematode suspension (40 IJs $/ \mathrm{cm}^{2}$ ) was sprayed in glass Petri dishes $(15 \mathrm{~cm} \varnothing \times 1.5 \mathrm{~cm})$, which were kept in a laminar flow chamber until the liquid was partially dry. Then, 10 workers were placed in these dishes where they stayed for $2 \mathrm{~h}$ (Carvalho et al., 2009).
After this period, the honey bees of two Petri dishes (totaling 20 bees) were transferred to PVC

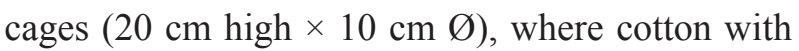
water and Candy paste were provided (Brighenti et al., 2007; Carvalho et al., 2009). The bioassay conditions and nematode death confirmation were the same as those described for bioassay 1 .

For the longevity data of A. mellifera workers, survival analysis was performed using the KaplanMeier estimator. The treatments were compared using the log-rank test., All analyses was done using the package 'survival' in R (R Core Team).

In bioassay 1, Steinernema nematode treatments reduced longevity (103.9, 96.3, and $99.6 \mathrm{~h})$ more than Heterorhabditis treatments (149.7, 126.8, and $134.7 \mathrm{~h}) . \mathrm{H}$. amazonensis $(149.7 \mathrm{~h})$ was the exception as it did not differ from the control (166.0 h) (Figure 1). The Steinernema nematodes, in this bioassay, were less selective for bees when compared to Heterorhabditis.

\section{Estimation of Kaplan-Meier $S(t)$ for the data Pulverization}

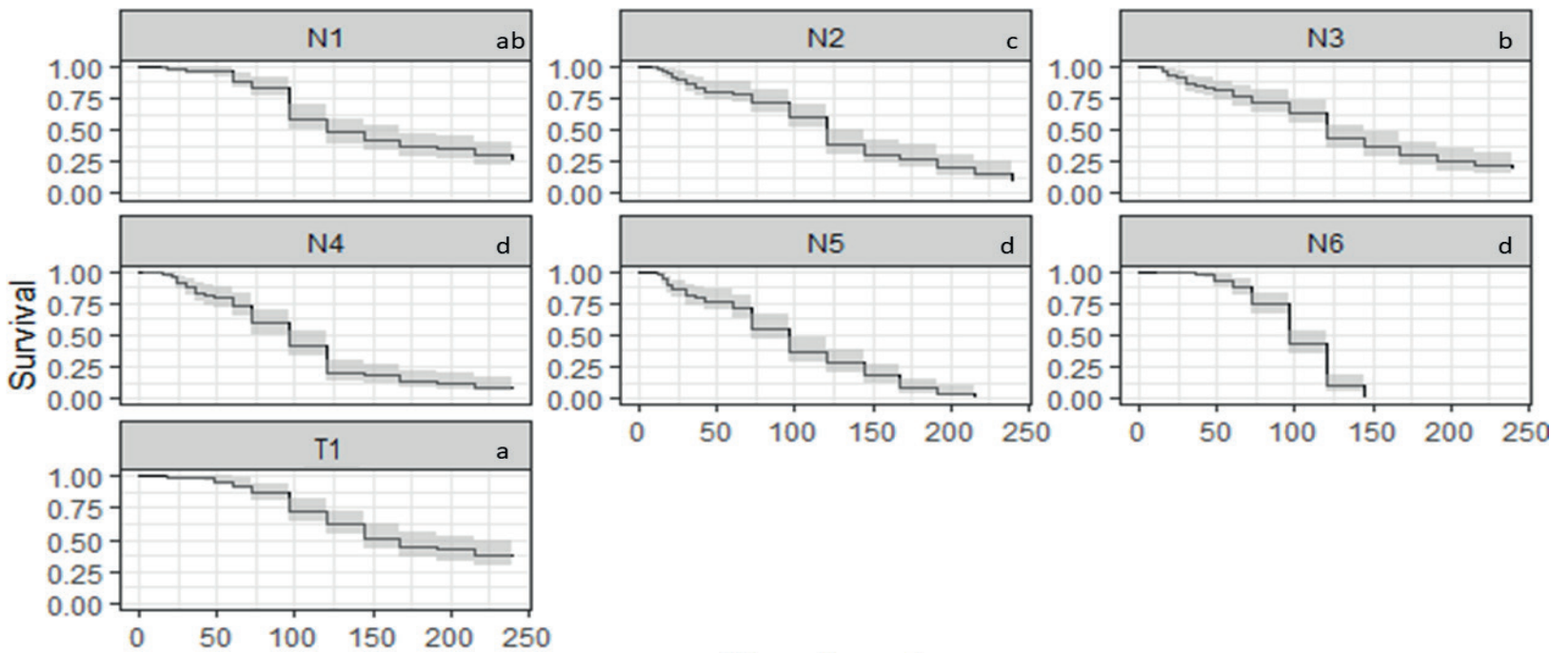

Time (hours)

Figure 1. Kaplan-Meier survival plot adjusted for time (hours) after entomopathogenic nematodes were sprayed on Africanized honey bees Apis mellifera workers (T1: Control, N1: Heterorhabditis amazonensis, N2: Heterorhabditis bacteriophora, N3: Heterorhabditis indica, N4: Steinernema carpocapsae, N5: Steinernema feltiae, N6: Steinernema rarum). Temperature at $26 \pm 2{ }^{\circ} \mathrm{C}$, relative humidity at $60 \pm 10 \%$, and $12 \mathrm{~h}$ photophase was maintained. Similar letters indicate no significant differences $(\mathrm{p}<0.05)$. 
In addition, at the end of $240 \mathrm{~h}$ of evaluation, $36 \%$ of the honey bees from the control treatment were alive, while in the nematode treatments only $26 \%$ were alive in $\mathrm{N} 1$ (H. amazonensis); $9 \%$ in N2 (H. bacteriophora); $19 \%$ in N3 (H. indica); $7 \%$ in N4 (S. carpocapsae); 0\% in N5 (S. feltiae), in which at $216 \mathrm{~h}$ none of the honey bees was alive); and $0 \%$ in N6 ( $S$. rarum), in which at $144 \mathrm{~h}$, all bees were dead.
In bioassay 2, all treatments reduced bee longevity ( 155.4 to $93.9 \mathrm{~h}$ ) compared to the control (176.1 hours) (Figure 2). At the end of 240 h, 43\% of the control treatment bees were alive. In the nematode treatments, $17 \%$ of the bees were alive in N2 (H. bacteriophora), 0\% in N4 (S. carpocapsae), $\mathrm{N} 5$ (S. feltiae), and N6 (S. rarum). All insects dissected after death, except the control, were infected by the nematodes, confirming the mortality due to the pathogen.

\section{Estimation of Kaplan-Meier S (t) for the data Contact}

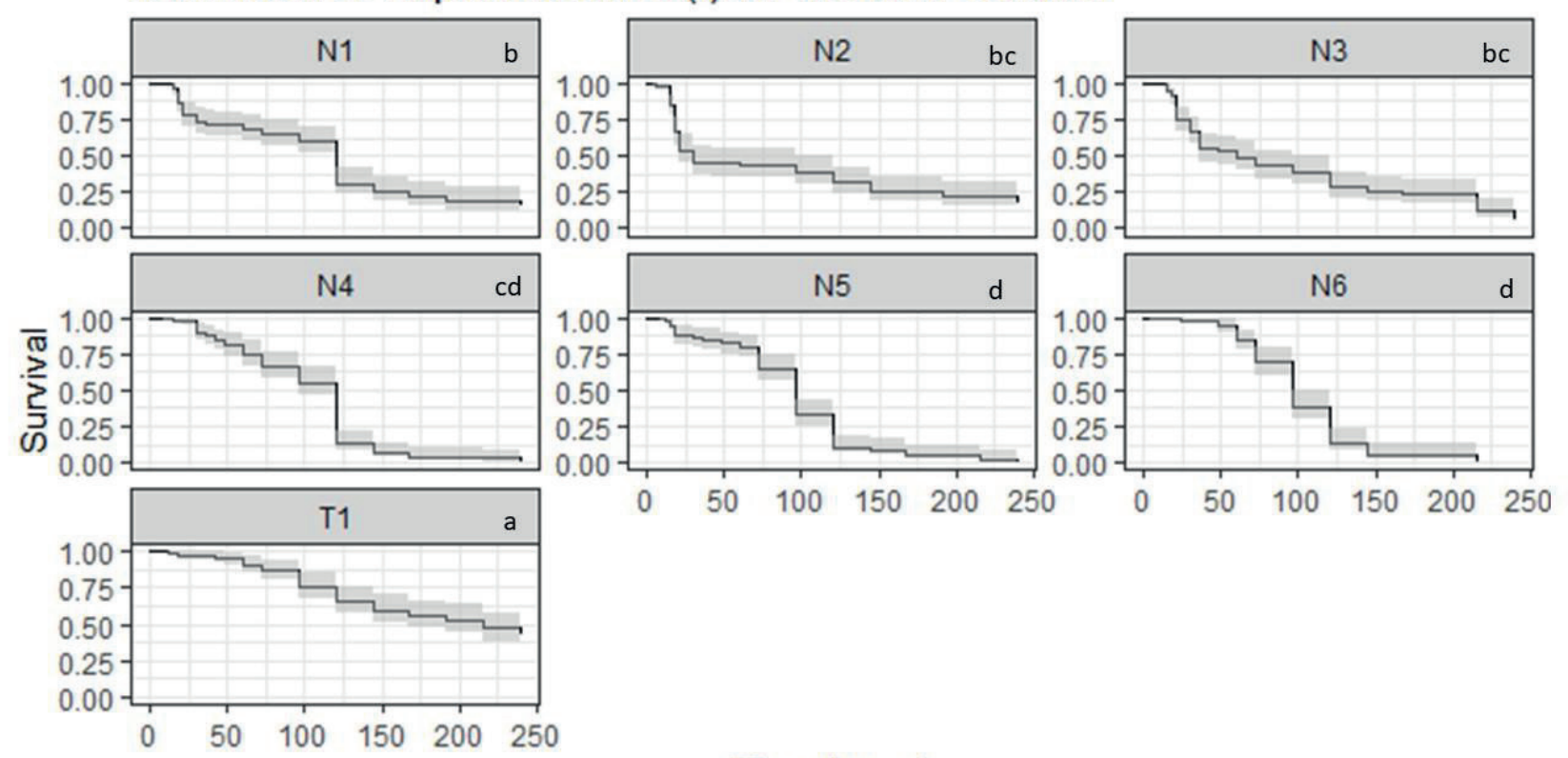

Time (hours)

Figure 2. Kaplan-Meier survival plot adjusted for time (hours) after contact of Africanized honey bees Apis mellifera workers with nematodes. T1: Control, N1: Heterorhabditis amazonensis, N2: Heterorhabditis bacteriophora, N3: Heterorhabditis indica, N4: Steinernema carpocapsae, N5: Steinernema feltiae, N6: Steinernema rarum). Temperature at $26 \pm 2{ }^{\circ} \mathrm{C}$, relative humidity at $60 \pm 10 \%$, and $12 \mathrm{~h}$ photophase was maintained. Similar letters indicate no significant differences $(\mathrm{p}<0.05)$.

The life cycle of entomopathogenic nematodes starts with the entry of infective juveniles (IJs) into the insect. Entry may occur through the mouth, spiracles, or anus. In the case of the genus Heterorhabditis, it may also occur through the integument due to the presence of a horn that punctures the insect integument. After penetration into the insect, the IJ migrates to the hemocele, where bacteria release and multiply producing toxins. Entomopathogenic nematodes feed on the multiplying bacteria and host insect tissue until they reach the fourth stage (J4). Inside the insect, these nematodes mate, and when the food resources run out (i.e., the host dies), reproduction stops and the IJ 
remains in the soil until they find another host insect to restart the cycle ( Lewis et al., 2006).

Products containing Heterorhabditis sp. and Steinernema sp., (50 nematodes per $\mathrm{cm}^{2}$ of soil) caused mortality in $80 \%$ of Bombus terrestris L. (Hymenoptera: Apidae) bees within 96 h (Dutka et al., 2015), corroborating data obtained in this study. Despite being bees of different species, both were sensitive to nematodes.

The entomopathogenic nematode $S$. feltiae (8 million JIs/L) reduced the emergence of the parasitoids Trichogramma chilonis, Ishii, 1941 (Hymenoptera: Trichogrammatidae) and Trichogramma japonicum, Ashmead, 1904 (Hymenoptera: Trichogrammatidae) (Sharma \& Aggarwal, 2019). These parasitoids belong to the same order as A. mellifera bees, which have similar morphological and physiological characteristics.

Entomopathogenic nematodes are agents found in and used mainly for the control of soil pests or insects that have at least one life stage in the soil. When used in biological control programs, aerial applications are infrequent. In addition, the encounter of this agent with bees in the wild is unlikely, but possible, which reduces the risks to populations of $A$. mellifera, although pathogenicity exists. These agents, especially those from the genus Steinernema, need to be tested for their behavior when other methodologies are used and for different times of exposure, besides being evaluated in the field because in these laboratory bioassays, they were poorly selective to $A$. mellifera workers.

\section{Acknowledgements}

We thank the CNPQ - Process 422269/2016-6 and CAPES for providing financial aid. We thank the State University of Londrina for providing the nematode strains and Federal University of Technology Paraná, Campus Dois Vizinhos.

\section{References}

Aristizábal, L. F., Ortiz, A. L., Quintero, J. C., LópezNuñez, J. C., Toro, H., \& Arthurs, S. P. (2015). Effect of Colombian strains of Steinernema colombiense (Rhabditida : Steinernematidae) and Heterorhabditis bacteriophora (Rhabditida: Heterorhabditidae) against Eurhizococcus colombianus (Hemiptera: Margarodidae) and Aeneolamia sp . (Hemiptera: Cercopidae). Florida Entomologist, 98(3), 981-983. doi: 10.1653/024.098.0330

Ballantyne, G., Baldock, K. C. R., Rendell, L., \& Willmer, P. G. (2017). Pollinator importance networks illustrate the crucial value of bees in a highly speciose plant community. Scientific Reports, 7(1), 1-13. doi: 10.1038/s41598-017-08798-x

Baptista, A. P. M., Carvalho, G. A., Carvalho, S. M., Carvalho, C. F., \& Bueno, J. S. S., F ${ }^{\circ}$. (2009). Toxicidade de produtos fitossanitários utilizados em citros para Apis mellifera. Ciência Rural, 39(4), 955-961. doi: 10.1590/S0103-84782009005000049. Recuperado de http://www.scopus.com/inward/ record.url?eid=2-s2.0-68949107820\&partnerID $=40$ \&md5=ba13c7d 735d48ae1456d5ee6b7933f27

Blackburn, D., Shapiro-ilan, D. I., \& Adams, B. J. (2016). Biological control and nutrition : Food for thought. Biological Control, 97(1), 1-8. doi: 10.1016/j. biocontrol.2016.03.007

Brighenti, D. M., Carvalho, C. F., Carvalho, G. A., Brighenti, C. R. G., \& Carvalho, S. M. (2007). Bioatividade do Bacillus thuringiensis var. kurstaki (Berliner, 1915) para adultos de Apis mellifera Linnaeus, 1758 (Hymenoptera: Apidae). Ciência e Agrotecnologia, 31(2), 279-289. doi: 10.1590/ s1413-70542007000200003

Calatayud-Vernich, P., Calatayud, F., Simó, E., SuarezVarela, M. M., \& Picó, Y. (2016). Influence of pesticide use in fruit orchards during blooming on honeybee mortality in 4 experimental apiaries. Science of The Total Environmen, 541(1), 33-41. doi: 10.1016/j.scitotenv.2015.08.131

Carvalho, S. M., Carvalho, G. A., Carvalho, C. F., Bueno, J. S. S., Fo., \& Baptista, A. P. M. (2009). Toxicidade de Acaricidas / inseticidas empregados na citricultura para a abelha africanizada Apis Mellifera L ., 1758 (Hymenoptera: Apidae). Arquivos do Instituto Biológico, 76(4), 597-606. doi: 10. 1590/s010384782009005000049 
Colombo, F. C., Maciel, R. M. A., Abati, R., RaulinoDomanski, F., Longhi, S. J., Costa-Maia, F. M., Vismara, E. S., Lozano, E. R. \& Potrich, M. (2020) Do Beauveria bassiana and Metarhizium anisopliae affect worker survival and the production of Africanized Apis mellifera queens?, Journal of Apicultural Research, 59(5) 1-10. doi: 10.1080/00218839.2020.1828237

Costa-Maia, F. M., Lino-Lourenço, D. A., \& Toledo, V. de A. A. de. (2010). Aspectos econômicos e sustentáveis da polinização por abelhas. In T. N. Martin, A. J. Waclawovsky, F. Kuss, A. S. Mendes, \& E. J. Brun (Eds.), Sistemas de produção agropecuária (ciências agrárias, animais e florestais) (pp. 45-67). Dois Vizinhos: Editora UTFPR.

Dutka, A., Mcnulty, A., \& Williamson, S. M. (2015). A new threat to bees? Entomopathogenic nematodes used in biological pest control cause rapid mortality in Bombus terrestris. PeerJ, 3(1), 1-9. doi: 10. $7717 /$ peerj. 1413

Hung, K.-L. J., Kingston, J. M., Albrecht, M., Holway, D. A., \& Kohn, J. R. (2018). The worldwide importance of honey bees as pollinators in natural habitats. Proceedings of the Royal Society B: Biological Sciences, 285(1870), 20172140. doi: 10.1098/ rspb.2017.2140
Lewis, E. E., Campbell, J., Gri, C., Kaya, H., \& Peters, A. (2006). Behavioral ecology of entomopathogenic nematodes. Biological Control, 38(1), 66-79. doi: 10.1016/j.biocontrol.2005.11.007.

Libardoni, G., Gouvea, A. de, Costa-Maia, F. M., Lozano, E. R., Freitas, P. F. de, Colombo, F. C. Potrich, M. (2018). Effect of different Bacillus thuringiensis strains on the longevity of Africanized honey bee. Semina: Ciências Agrárias, 39(1), 329-337. doi: 10.5433/1679-0359.2018v39n1p329

Molina, J. P., \& López, N. J. C. (2001). Producción in vivo de tres entomonematodos con dos sistemas de infección en dos hospedantes. Revista Colombiana de Entomología, 27(1-2), 73-78.

Oliveira, M. O. de. (2015). Declínio populacional das abelhas polinizadoras de culturas agrícolas. Acta Apicola Brasilica, 3(2), 1-6. doi: 10.18378/aab. v3i2.3623

Pires, C. S. S., Pereira, F. de M., Lopes, M. T. do R., Nocelli, R. C. F., Malaspina, O., Pettis, J. S., \& Teixeira, É. W. (2016). Enfraquecimento e perda de colônias de abelhas no Brasil : há casos de CCD ? Pesquisa Agropecuária Brasileira, 51(5), 422-442. doi: 10.1590/S0100-204X2016000500003

Sharma, S., \& Aggarwal, N. (2019). Safety assessment of selected biopesticides and botanicals on Trichogramma spp. (Hymenoptera: Trichogrammatidae) in fields. Indian Journal of Experimental Biology, 57(6), 443-449. 
